\title{
FENOMENA PEMUJAAN RATU NIANG DI KOTA DENPASAR
}

\author{
Oleh: \\ I Made Surawati \\ I Nyoman Putra Adnyana \\ Universitas Hindu Indonesia \\ e-mail: madesurawati@yahoo.co.id
}

\begin{abstract}
Before the Hinduism began to influence the Balinese culture, the Balinese society had been applying symbols as one part of their ritual tradition. One of the symbols was in the form of feminine force. This has been applied as the symbol of fertility which has been traditionally handed down. In the city of Denpasar, there is similar tradition, in which the feminine force is manifested under the believe that the citizen would be bestowed with successful supports, especially for those who have business occupation. The manifestation is in the form of Ratu Niang, as the representation of the Almighty God. In this manifestation, God is belived to bless the community to successfully improve their prosperity and welfare. In Denpasar, there are several sites of this Ratu Niang worship, the unique one is located at Prima Medika Hospital, on the South part of Jero Kuta and the biggest one is at Pura Geria Anyar Tanah Kilap.
\end{abstract}

Keywords: phenomenon, Ratu Niang worship

\begin{abstract}
Abstrak
Masyarakat Bali sebelum masuknya pengaruh Hindu memiliki tradisi pemujaan dengan menggunakan simbol-simbol. Salah satu simbol yang digunakan adalah perempuan sebagai simbol kesuburan. Tradisi ini rupanya berlanjut terus hingga saat ini. Di Kota Denpasar terdapat suatu bentuk kepercayaan terhadap simbol perempuan yang diyakini memiliki kemampuan untuk memberikan dukungan kesuksesan bagi mereka yang meyakininya, khususnya mereka yang bergerak di bidang bisnis. Tersebutlah Ratu Niyang yang diyakini sebagai manifestasi Yang Kuasa yang memiliki kemampuan membantu masyarakat dalam mewujudkan kemakmuran dan kesejahteraan. Di Kota Denpasar terdapat beberapa lokasi sebagai tempat pemujaan Ratu Niyang yaitu di Rumah Sakit Prema Medika, di sisi selatan Jero Kuta, dan yang terbesar adalah di Pura Geria Anyar Tanah Kilap.
\end{abstract}

Kata kunci: Fenomena, Pemujaan Ratu Niang

\section{PENDAHULUAN}

Sebelum agama Hindu masukke Bali, masyarakat telah memiliki sistem kepercayaan dalam bentuk kepercayaan lokal. Masuknya pengaruh Hindu ke Indonesia menyebabkan terjadinya proses kontestasi antara bentuk-bentuk kepercayaan Indonesia dengan agama Hindu yang datang dari India. Proses interaksi terjadi secara akulturatif, unsur-unsur asing diolah ke dalam kebudayaan lokal tanpa hilangnya kepribadian dasar kebudayaan lokal (Geria, 2000: 
3). Oleh karena itu, masuknya unsur India sebaiknya dianggap sebagai zat penyubur yang menumbuhkan agama Hindu Indonesia yang tetap memperlihatkan kekhasannya (Bosch, 1983: 7).

Pandangan-pandangan ini menunjukkan bahwa kebudayaan Indonesia (Bali) ketika terjadi proses akulturasi dengan kebudayaan India (Hindu) telah berada dalam posisi yang cukup kuat sehingga terjadilah proses dialektis dan tidak terjadi dominasi. Bukti-bukti yang menunjukkan bahwa kebudayaan Bali sudah mencapai tingkat yang cukup tinggi ketika proses akulturasi itu terjadi antara lain sebagai berikut: (1) Kepercayaan tentang gunung dan laut sebagai alam roh; (2) Kepercayaan adanya alam nyata dan tidak nyata; (3) Adanya kepercayaan bahwa setelah mati, ada kehidupan lain dan akan menjelma kembali; (4) Adanya kepercayaan bahwa organ-organ tubuh tertentu terutama penis dan vagina memiliki kekuatan sebagai penolak bala; (5) Adanya kepercayaan terhadap roh nenek moyang atau leluhur yang dapat dimintai pertolongan (Sutaba,1980: 30-32; Pemda Bali, 1985/1986: 52-53; Ardana, 1986: 75-76).

Seiring perkembangan jaman agama dan masyarakat mengalami perkembangan sehingga terjadilah perubahan-perubahan baik yang berlangsung secara alami maupun hasil konstruksi masyarakat sebagai pendukung budaya dan agama, yaitu: dinamika dari masyarakat tradisional menuju masyarakat modern.

Masyarakat Bali boleh dikatakan belum mengalami malapetaka kehidupan modern seperti yang dialami masyarakat di negara-negara maju, karena modernitas atau kemodernan masyarakat Bali baru dalam pertumbuhan awal. Namun demikian masyarakat yang berada pada masa transisi dari tradisional ke modern, seringkali memunculkan persoalan yang tidak kalah rumitnya. Secara fisik masyarakat Bali nampak modern namun dalam kehidupan mental dan alam pikiran masih tradisional. Tradisi lama belum ditinggalkan sementara pola pikir modern belum dikuasai. Kalau memijam pemikiran Comte (dalam Koento Wibisono: 1983) masyarakat berdiri dalam kondisi satu kaki pada tahap teologi sementara kaki lainnya pada tahap positif.

Yang jelas bahwa manusia dewasa ini makin sadar bahwa seluruh krisis di bumi ini tidak hanya disebabkan oleh alasan material tapi justru lebih pada sebab-sebab transendental. Dunia modern sekarang ini tidak lagi memiliki horizon spiritual. Manusia modern melihat segala sesuatu hanya dari sudut pandang pinggiran eksistensi, tidak pada "pusat spiritualitas diri" sehingga mengakibatkan ia lupa siapa dirinya. Perhatian lebih terpusat pada dunia materi memang telah memberikan kemajuan yang sangat mengagumkan, tapi secara kualitatif dan keseluruhan tujuan hidup ternyata sangat dangkal. Dekadensi atau kejatuhan manusia saat ini telah kehilangan pengetahuan tentang diri, dan menjadi sangat tergantung pada pengetahuan eksternal, yang tak langsung berhubungan dengan dirinya (Hidayat, 2003).

Kecenderungan ini terjadi karena proses rasionalisasi yang menyertai modernitas telah menciptakan sekularisasi kesadaran dan memperlemah fungsi kanopi suci agama dari domain kehidupan para pemeluknya, sehingga menimbulkan ketidakberartian pada diri manusia modern. Hal-hal sakral yang berfungsi sebagai faktor sublimasi dan penguatan eksistensi manusia, digantikan oleh hal-hal yang sertba rasional sehingga terjadilah dekonstruksi transendensi kognisi manusia atau dengan istilah sekularisasi alam bathin (Nashir, 1999).

Dari paparan tersebut di atas semakin tampak bahwa agama memang diperlukan dalam menata perilaku manusia. Hal ini menjadi penting karena pengalaman manusia yang diperoleh dari ketidakpastian, ketidakberdayaan dan kelangkaan yang memang merupakan karakteristik fundamental kondisi manusia. Dalam hal ini fungsi agama adalah menyediakan dua hal. Pertama, memberikan suatu cakrawala pandang tentang dunia luar yang tak terjangkau oleh manusia, dalam arti deprivasi dan frustasi dapat dialami sebagai sesuatu yang mempunyai makna. Kedua, menyediakan sarana ritual yang memungkinkan hubungan manusia dengan hal di luar jangkauan, memberikan jaminan dan keselamatan bagi manusia mempertahankan moral (O'Dea, 1985).

Untuk mampu mempertahankan eksistensi moral dari persoalan-persoalan yang dihadapi, manusia membutuhkan agama sebab menurut O’Dea (1985) agama paling tidak mempunyai 6 (enam) fungsi yaitu:

1. Agama mendasarkan perhatiannya pada sesuatu yang di luar jangkauan manusia yang melibatkan takdir dan kesejahteraan, menyediakan bagi pemeluknya 
suatu dukungan, pelipur lara dan rekonsiliasi. Manusia membutuhkan dukungan moral di saat menghadapi ketidakpastian, pelipur lara di saat berhadapan dengan kekecewaan dan rekonsiliasi dengan masyarakat bila diasingkan dari tujuan dan norma-normanya.

2. Agama menyediakan hubungan transendental melalui upacara dan pemujaan, mampu memberikan dasar emosional bagi rasa aman serta identitas lebih kuat.

3. Agama mensucikan norma-norma dan nilai-nilai masyarakat yang telah dibentuk, sehingga memposisikan dominasi tujuan kelompok di atas tujuan individual.

4. Agama juga mempunyai fungsi untuk mengkaji kembali nilai-nilai dan normanorma yang telah terlembaga, bila memang masyarakat membutuhkannya.

5. Agama melakukan fungsi-fungsi identitas yang penting, melalui peran serta manusia di dalam ritual agama dan doa, sehingga mereka melakukan unsur-unsur signifikan yang ada dalam identitas.

6. Agama bersangkut paut dengan pertumbuhan dan kedewasaan individu, dan perjalan hidup melalui tingkat usia yang ditentukan oleh masyarakat.

Ringkasnya secara fungsional, agama mengidentifikasikan individu dengan kelompok, menolong individu dalam ketidakpastian, menghibur ketika dilanda kecewa, mengaitkannya dengan tujuan-tujuan masyarakat, memperkuat moral, dan menyediakan unsur-unsur identitas.

Meskipun masyarakat Hindu di Bali khususnya di Kota Denpasar mengalami perubahan dari masyarakat tradisional menuju masyarakat modern, bentuk-bentuk kepercayaan itu hingga saat ini masih tetap hidup dalam masyarakat Hindu. Salah satunya adalah dalam bentuk kepercayaan lokal yang masih berkembang hingga saat ini adalah pemujaan Ratu Niyang. Hasil penjajagan awal di lapangan menunjukkan bahwa di Kota Denpasar terdapat beberapa tempat pemujaan Ratu Niyang yaitu di tepi Tukad Badung di Jalan Kartini Denpasar, di Rumah Sakit Prema Medika, dan yang terbesar adalah yang terdapat di Desa Suwung Kauh Denpasar Selatan. Ketiga lokasi ini terletak pada daerah aliran sungai Badung (tukad Badung).

Berdasarkan paparan tersebut di atas ke- beradaan pemujaan Ratu Niang di Kota Denpasar menjadi sangat menarik untuk diteliti lebih lanjut sehingga akan diperoleh informasi yang memadai tentang keberadaan pemujaan Ratu Niang di Kota Denpasar, sebagai bentuk kepercayaan lokal yang masih bertahan hingga saat ini. Di sini ada tiga topic bahasan yakni bentuk pemujaan RatuNiang, fungsi pemujaan Ratu Niang dan makna keberadaan pemujaan Ratu Niang di Kota Denpasar.

\section{PEMBAHASAN}

\subsection{Asal Usul Pemujaan Ratu Niang}

Ketika menelusuri asal usul pemujaan Ratu Niang di Kota Denpasar, sangat sulit menemukan sumber-sumber berupa artefak. Namun demikian menurut pandangan pandangan panglingsir pura Tanah Kilap Wayan Cepog Suradnya, pemujaan Ratu Niang ada hubungannya dengan kisah perjalanan Danghyang Nirartha di Bali. Dikisahkan perjalanan Danghyang Nirartha dari Jawa Timur ke Bali. Setelah beristirahat sejenak di Pura Ancak beliau melanjutkan perjalanan ke arah timur. Dalam perjalanan tiba-tiba beliau bertemu dengan seekor naga yang menegangkan mulutnya bagaikan sebuah goa. Masuklah beliau ke dalam mulut naga tersebut. Di dalamnya ditemukan telaga dengan bunga tunjung sedang mekar, ada yang putih, merah dan hitam. Lalu dipetiknya bungan-bunga tersebut.

Ketika beliau keluar dari mulut naga tersebut, sirnalah naga tersebut dan wajah Danghyang Nirartha berubah-ubah menyeramkan, terkadang merah, hitam, dan putih silih berganti. Hal ini membuat para istri dan anaknya menjadi ketakutan. Ida Ayu Swabawa sirna sebagai dewa wong Sumedang dan disembah sebagai Dewi Pasar. Ibunda beliau Sri Patni Kaniten sirna di Pulaki menjadi Batari Dalem Pulaki. Demikian juga putrinya yang bernama Ida Rai Istri, ketika mengikuti perjalanan Danghyang Nirartha, lalu sirna di alas sepi bernama Suwung, disembah di pura Tanah Kilap, Desa Suwung Badung, bergelar batari Lingsir bergelar Ratu Niang Sakti.

Wayan Cepog menyatakan bahwa pura ini didirikan sekitar tahun 1962, sekitar tiga bulan setelah pasamuan agung Parisada Hindu Dharma Bali di Campuhan Ubud. Diceritakan pada waktu itu Dinas PU Kabupaten Badung berencana membangun jembatan di sebelah barat lokasi pura untuk menghubungkan jalan-jalan. 
Dalam pengerjaannya, jembatan tersebut selalu gagal. Ada saja hambatan yang dihadapi. Suatu ketika, terjadi suatu fenomena gaib. Ida Bhatara mengejawantahkan diri sebagai sosok wanita tua (anak lingsir meraga istri) di hadapan Kabag Bendungan Dinas PU saat itu. Sosok anak lingsir maraga istri tersebut kemudian berkata, intinya kurang lebih sebagai berikut. Jika tidak dibuatkan "rumah" kapan pun jembatan yang dibangun tidak akan berhasil. Sosok wanita tersebut kini sering muncul di sekitar pura.

Singkat cerita akhirnya dibangunlah palinggih yang pada awalnya hanya terdiri dari Padmasari dan pemayasan di atas tanah yang awalnya hanya setengah are. Sekarang luas pura sudah 17,8 are. Setelah didirikan palinggih tersebut, jembatan yang dibangun Dinas PU itu bisa dikerjakan secara lancar.

Seiring perjalanan waktu, Pura Geria Anyar Tanah Kilap mengalami renovasi tahun 1992. Awalnya hanya padmasari kemudian dilengkapi sejumlah palingggih lainnya. Di pura tersebut selain terdapat palinggih gedong stana Ida Bhatara Ratu Niang Sakti, juga palinggih sthana Danghyang Nirartha, palinggih Ida Bhatara Gde Macaling atau Ida Bhatara Ratu Gde Sakti Dalem Peed, palinggih Ida Bhatara Segara, Melanting dan sebagainya. Sebagai pangemong pura adalah Banjar Gelogor Carik.

Demikianlah mitos tentang pemujaan Ratu Niang di Pura Geria Anyar Tanah Kilap yang berada di wilayah mura sungai atau Tukad Badung. Pura ini merupakan tempat pemujaan Ratu Niyang yang terbesar di Denpasar. Di beberapa tempat juga ditemukan tempat pemujaan Ratu Niyang Sakti.

Apabila ditelusuri dari arah hulu sungai Badung ke arah hilir maka akan ditemukan juga tempat pemujaan Ratu Niyang Sakti seperti di wilayah Rumah Sakit Prima Medika, dan di sisi selatan Puri Jero Kuta Denpasar.

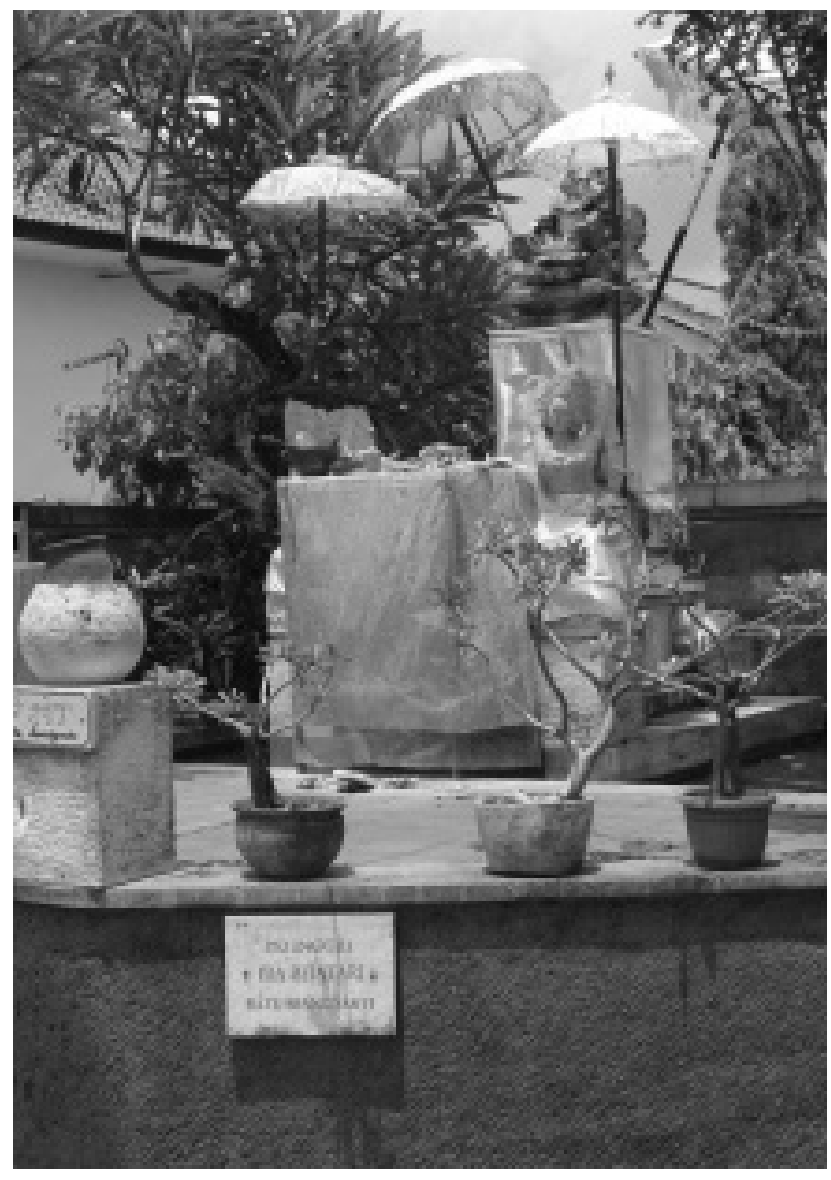

Tempat Pemujaan Ratu Niyang di RS Prima Medika

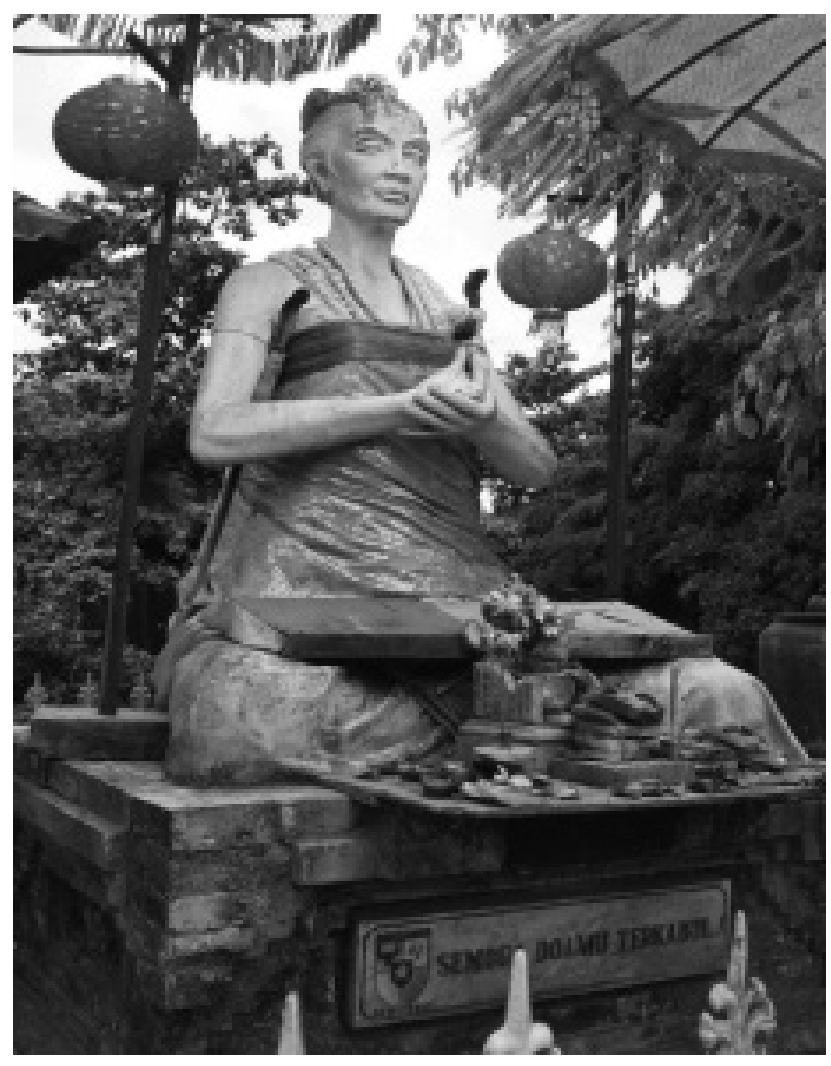

Palinggih Ratu Niyang di sisi selatan Puri Jero Kuta Denpasar 
Jika dicermati kisah tersebut di atas, rupanya tokoh perempuan menjadi tokoh sentral terutama dalam kaitannya dengan persoalan perekonomian atau terkait masalah kemakmuran secara umum seperti Melanting. Tradisi ini rupanya merupakan kelanjutan dari tradisi pra Hindu yang memandang bahwa perempuan sebagai simbol kesuburan.

\subsection{Fungsi Pemujaan Ratu Niang}

Masyarakat yang datang menghaturkan sembah di Pura Geria Anyar Tanah Kilap Suwung meyakini bahwa Ida Sanghyang Widhi dengan segala prabawaNya bersthana di pura ini sangat pemurah dan mampu memberikan kesejahteraan bagi masyarakat yang meyakininya. Dari hasil wawancara dengan I Wayan Enteg terungkap sebagai berikut:

"Tiang sering maturan meriki, pinaka bhaktin tiang santukan napi sane aptiang tiang prasida kadagingin. Tiang anak dados dagang, pinunase wantah mangde dagangan tiange laku. Apang wenten tunas anggen masukkang panak sekolahan. Ida Ratu Niyang anak bares yening irage rajin lan yakin ring ida"

Terjemahan bebasnya:

"Saya selalu bhakti menyampaikan rasa sukur saya ke pura ini, sebab selama ini segala doa saya terkabulkan. Saya adalah seorang pedagang, permohonan saya tentulah agar dagangan saya laku terjuah sehinggi saya punya biaya hidup untuk keluarga dan biaya sekolah anak-anak saya. Ratu Niyang sangat dermawan jika kira rajin dan yakin“

Dari paparan tersebut di atas menunjukkan bahwa pemujaan Ratu Niyang Sakti di Pura Geria Anyar Tanah Kilap erat kaitannya dengan persoalan ekonomi. Boleh dikatakan bahwa pemujaan Ratu Niyang di Pura ini sebagai Pura Swagina (fungsional).

Berdasarkan karakteristiknya ribuan Pura yang terdapat di Pulau Bali diklasifikasikan menjadi empat kelompok: (1) Pura Kahyangan Jagat, yaitu pura umum tempat pemujaan Sang Hyang Widhi Wasa, Tuhan Yang Maha Esa dalam segala manifestasi-Nya, roh suci para tokoh masyarakat seperti pendeta dan penguasa. Yang termasuk di dalamnya adalah Pura Sad Kahyangan, yaitu enam pura terbesar di Pulau Bali dan Pura Dang Kahyangan, (2) Pura Kahyangan De$s a$, yaitu pura tertorial tempat pemujaan warga desa adat, (3) Pura Swagina (Pura fungsional) yaitu pura yang penyiwinya terikat pada pencaharian seperti Pura Subak, Pura Melanting dan yang sejenisnya. (4) Pura Kawitan, yaitu pura yang penyiwinya seperti Sanggah/Merajan, Pertiwi, Ibu, Panti, Dadia, Batur, Penataran Dadia, Dalem Dadia, Pedharman dan yang sejenisnya.

Ditegaskan pula bahwa selain kelompok pura yang mempunyai fungsi dan karakterisasi seperti tersebut di atas, terdapat pula pura yang berfungsi di samping untuk memuja Hyang Widhi Wasa atau Prabawa-Nya, juga berfungsi untuk memuja Atma Sidha Dewata (Roh Suci Leluhur).

Keberadaan Pura Geria Anyar Tanah Kilap sebagai tempat pemujaan Ratu Niyang Sakti juga tidak bisa dilepaskan dari fungsi religius. Setidaknya keberadaan pura ini turut berperan dalam membangun semangat religius masyarakat, khususnya masyarakat penyungsung Pura. Seperti diketahui, dan sesuai dengan wawancara bersama Ketut Rai (45 tahun, pedagang dari Monang Maning Denpasar), keberadaan Pura memang sangat penting dalam membangun kesadaran religius masyarakat khususnya di Denpasar dan sekitarnya.

"Saya beserta keluarga selalu hadir menghaturkan bhakti pada saat piodalan atau pada hari-hari suci Hindu lainnya “

Betapa tidak sejak Pura Geria Anyar Tanah Kilap berdiri hingga kini, masyarakat penyungsung masih rutin melakukan aktivitas religius dari yang sifatnya paling sederhana yakni menghaturkan canang sari dan banten saat purnamatilem, sampai pada menggelar upacara piodalan. Hal ini dilakukan semata-mata untuk memuja Ida Bhatara memohon agar umat manusia diberkati kerayahuan dan kerahajengan. Bisa dikatakan keberadaan Pura Geria Anyar Tanah Kilap sebagai penopang aktivitas religius masyarakat penyungsung.

Adapun beberapa aktivitas religi yang dilakukan yakni setiap enam bulan sekali tepatnya Anggara Kasih Tambir melaksanakan upacara piodalan di Pura. 
Seperti yang disampaikan I Wayan Kona (39 tahun, Pamangku), keberadaan Pura Geria Anyar Tanah Kilap ini setidaknya berdampak pada munculnya kesadaran-kesadaran religi di kalangan masyarakat sekitar. Dari sini bisa disimpulkan jika keberadaan Pura Geria Anyar Tanah Kilap ini secara langsung memiliki fungsi membangun kembali kesadaran religius masyarakat. Dengan adanya Pura Geria Anyar Tanah Kilap masyarakat pun seolah diikat dalam satu ikatan spiritual dan religius untuk memuja Ida Bhatara di Pura Geria Anyar Tanah Kilap. Secara sederhana, ketika ada Pura Geria Anyar Tanah Kilap, maka masyarakat wajib untuk melaksanakan upacara baik upacara ritual bersaji sampai pada pemujaan terhadap Ida Bhatara yang berstana di sana. Secara sederhana, di mana ada tempat suci, maka di sana pula akan ada para bakta atau pemuja, orang suci, dan upacara-upacara suci. Begitu pula yang terjadi di Pura Geria Anyar Tanah Kilap ini.

Sementara itu menurut keterangan Ni Wayan Mariani (51 tahun, Pamangku) selain masyarakat panyungsung, pada saat piodalan dan harihari suci Hindu banyak masyarakat umum juga hadir menghaturkan bhakti di pura Geria Anyar.

"Sane rauh tangkil mariki wenten saking Tabanan, Gianyar, Klungkung, lan sane lianan. Yen odalan rame pisan di Pura"

Selain memiliki fungsi religius seperti yang dijelaskan pada sub bab sebelumnya, keberadaan Pura Geria Anyar Tanah Kilap juga memiliki fungsi secara sosial. Fungsi upacaraupacara secara sosial sesuai dengan pandangan seorang sosiolog Prancis Emile Durkheim dalam bukunya yang terkenal The Elementary Forms the Religius Life (2011). Durkheim menyatakan bahwa agama adalah sebuah sistem keyakinan dan praktek yang disatukan dengan hal-hal yang sakral, yakni hal-hal yang disisihkan dan terlarang - keyakinan dan praktek-praktek yang menyatukan segala hal yang terkait dengan komunitas moral tunggal (Turner, 2006: 80).

Selanjutnya Durkheim (Turner, 2006: 83) menjelaskan bahwa agama sebenarnya tidak berisi keimanan kepada roh-roh atau dewa-dewa, akan tetapi agama didirikan atas pembedaan kategoris antara dunia yang sakral berhadapan dengan dunia profan. Bagi Durkheim keyakinan dan ritus-ritus religious merupakan fakta-fakta sosial yang juga memiliki fungsi integrasi dan menjalin sebuah solidaritas sosial.

Durkheim (Triguna, 1997: 98) beragumentasi manusia mengembangkan aktivitas religi bukan karena alam supranatural, tidak pula karena kagum akan kekuatan alam, tidak juga karena ada bayangan abstrak tentang suatu kekuatan yang menyebabkan adanya gerak, tetapi Karena getaran jiwa yang timbul karena rasa sentiment kemasyarakatan. Wujud dari rasa sentiment kemasyarakatan adalah rasa terikat, rasa bakti, rasa cinta terhadap masyarakat karena manusia merasakan kekuatan gagasan kolektif. Gagasan yang dikemukakan Durkheim ini mewakili apa yang terjadi di Pura Geria Anyar Tanah Kilap tempat pemujaan Ratu Niyang.

Dalam arti Pura Geria Anyar Tanah Kilap tempat pemujaan Ratu Niyang ini memiliki peran penting dalam memperkuat ikatan sosial masyarakat penyungsung pura ini.

Pertama, agama telah membantu mendorong terciptanya persetujuan mengenai sifat dan isi kewajiban-kewajiban sosial tersebut dengan memberikan nilai-nilai yang berfungsi menyalurkan sikap-sikap anggota masyarakat dan menetapkan isi dari kewajiban-kewajiban sosial mereka. Dalam hal ini agama telah membantu menciptakan sistem-sistem nilai sosial yang terpadu dan utuh. Sangatlah sulit bagi manusia untuk dalam jangka waktu yang cukup lama tetap bersepakat mengatur tingkah laku mereka sesuai dengan bermacam-macam larangan dan perintah yang satu sama lainnya tidak bertalian. Banyak krisis disiplin dalam masyarakat, seperti disiplin sekolah, lalu lintas cenderung menjadi gagal ketika penegakan disiplin itu semata-mata ditekankan dengan menggunakan kekuatan fisik. Di samping itu banyak contoh telah menunjukkan bahwa masyarakat tidak dapat dipertahankan keutuhannya dalam jangka waktu yang panjang jika hanya menggunakan kekuatan fisik. Dari dimensi ini, kemampuan menghargai norma dan nilai sosial budaya merupakan hal penting yang mutlak dilakukan kepada umat beragama.

Apabila masyarakat diharapkan tetap stabil dan tingkah laku sosial masyarakat bisa tertib dan baik maka tingkah laku yang baik harus ditata dan dipolakan sesuai prinsip-prinsip tertentu yang relatif diterima dan disepakati bersama. Prinsip-prinsip dasar tersebut berkaitan dengan tujuan-tujuan atau sasaran utama 
tingkah laku sosial manusia. Tujuan-tujuan semacam itu disebut dengan nilai-nilai. Pada saat nilai-nilai suatu masyarakat dapat diintegrasikan dalam suatu tatanan atau sistem yang berarti, pada saat itulah anggota masyarakat dapat bersatu menuju ke satu arah dalam tingkah laku mereka, dan hal ini mungkin tidak akan pernah terwujud dengan sempurna. Nilainilai yang dipegang dan dipedomani dalam suatu masyarakat biasanya berjenjang dan berstruktur. Dalam hirarki ini agama menduduki jenjang yang tertinggi meskipun seringkali tidak disadari oleh masyarakat. Dengan demikian dapat dikatakan bahwa agama dalam hal ini adalah sebagai pengintegrasi nilai-nilai yang dipegang oleh suatu masyarakat.

Kedua, agama juga memainkan peranan penting dalam memberikan kekuatan memaksa yang mendukung dan memperkuat adat istiadat. Sikap mengagungkan dan rasa hormat terutama yang berkaitan dengan adat istiadat (sistem moral) yang berlaku. Berhubungan erat dengan perasaan-perasaan kagum yang ditimbulkan oleh yang sakral itu sendiri (Nottingham, 1992: 36). Sebagaimana dimaklumi bahwa masyarakat Hindu Bali dikenal memiliki dan menjunjung tinggi adat istiadat. Mungkin sering kali muncul pertanyaan apa yang menyebabkan adat istiadat itu memiliki kekuatan memaksa sehingga orang mau melaksanakannya ? Ada satu hal yang menjadi kunci jawaban dari pertanyaan itu adalah adanya nilai-nilai agama yang memberi roh bagi pelaksanaan adat istiadat itu. Dengan adanya norma-norma agama memungkinkan disesuaikannya tingkah laku manusia dengan norma-norma tersebut. Namun penyesuaian dengan norma-norma tersebut akan lebih memiliki kekuatan memaksa, apabila hal itu disertai dengan ganjaran-ganjaran.

Ganjaran dan hukuman sosial (sanksi sosial) tersebut sampai taraf tertentu masih diakui dalam semua norma sosial, hanya saja kebanyakan orang mau menyesuaikan diri dengan norma-norma itu karena pernah menerima sanksi atau cemohan dari teman-temannya. Jika norma-norma tersebut dikaitkan dalam kerangka yang sakral maka sanksinya pun dikaitkan dengan hal-hal yang bersifat sakral. Dengan demikian dapat dikatakan bahwa agama telah memberikan dasar yang kuat bagi penetapan norma-norma sosial dalam masyarakat sehingga norma-norma sosial itu mempunyai kekua- tan memaksa untuk menata perilaku masyarakat. Dengan menempatkan agama sebagai norma tertinggi sebagai pola rujukan tingkah laku, ganjaran yang diterimapun tidak hanya bersifat duniawi, tetapi juga dunia yang lain, selain dunia nyata ini.

\subsection{Makna Keberadaan Pemujaan Ratu Niang}

Kehadiran Pura Geria Anyar Tanah Kilap sebagai tempat pemujaan Ratu Niyang, telah memberikan vibrasi positif terhadap proses pengembangan keimanan kepada Tuhan/Sang Hyang Widhi Wasa bagi masyarakat. Hal ini disampaikan oleh seorang pamedekyang sering ngaturang bhakti di pura tersebut dalam sebuah wawancara dengan I Wayan Enteg sebagai berikut.

"Tiang bersama keluarga sering tangkil ngaturang bhakti ring Ratu Niyang, nunas swecan Ida mangdane tiang sekeluarga rahayu, polih rejeki anggen keluarga. Rasanya nyaman dan tentram sekali setelah ngaturan bhakti driki. Yening wenten pikobet tiang taler nunas ica ring Ida" (Luh Suwartini, 45 tahun, pedagang alatalat upacara).

Terjemahan bebasnya:

"Saya sekeluarga sering menghaturkan semabh kepada Ratu Niyang, memohon agar kami sekeluarga rahayu serta dimudahkan rejekinya dalam berusaha dagang. Rasanya sangat nyaman dan tentram manakala kami menghaturkan bhakti di sini. Jika ada persoalan dalam hidup kami yang sangat sulit untuk diatasi kami mohon petunjukNYA di sini"

Hal senada juga diungkapkan oleh informan lainnya yaitu I Wayan Suadi (42 tahun, berprofesi sebagai pedagang alat-alat upacara) sebagai berikut.

"Ratu Niyang sangat suweca ring panjak dane. Yening sampun kayu berusaha lan teleb memuja Ida, sinah napi sane kaapti pacang kadagingin" 
Artinya:

"Ratu Niyang sangat pemurah, jika kita mau rajin berusaha dan juga meyakini keberadaan belaiu pastinya beliau memberikan anugrahNYA".

Agama berkaitan dengan usaha-usaha manusia untuk mengukur dalamnya makna dari keberadaannya sendiri dan keberadaan alam semesta. Selain itu, agama juga dapat membangkitkan kebahagiaan batin yang paling sempurna dan juga perasaan takut dan ngeri. Meskipun perhatian ditujukan kepada adanya suatu dunia yang tidak dapat dilihat (akhirat), namun agama melibatkan dirinya dalam masalah-masalah kehidupan sehari-hari di dunia.

Agama seringkali bersifat paradoks, di satu sisi agama dijalani sebagai jalan penjamin menuju keselamatan, cinta, dan perdamaian; sementara itu, di pihak lainnya agama justru menjadi sumber penyebab dan alasan bagi kehancuran dan kemalangan umat manusia. Mungkin, ungkapan yang menyatakan bahwa manusia akan hidup lebih baik dan tertib serta bahagia, jikalau hidupnya tanpa agama, seolah-olah benar adanya. Oleh karena agama orang bisa saling mencinta, tetapi atas nama agama pula orang bisa saling membunuh dan menghancurkan (Sindhunata, 2003: 13).

Sampai di sini agama tampaknya plin-plan terhadap eksistensi manusia, agama menyebabkan kebahagiaan dan agama juga menyebabkan kesengsaraan; atau agama yang menyebabkan dan menciptakan kedamaian dan kelestarian, tetapi agama juga yang menyebabkan peperangan dan kehancuran. Oleh karena itu seolaholah agama memiliki kepribadian ganda (doubel personality), yang satu lembut dan melankolis, sedangkan yang lain kasar dan keras.

Berkaitan dengan kepribadian yang kedua, agama sebagai yang bersifat kasar dan keras, beberapa catatan sejarah menunjukkan bahwa agama telah menjadi pemicu permusuhan di beberapa tempat, tetapi harus pula diakui bahwa agama telah berhasil memberikan nilai dan arti bagi kehidupan umat manusia. Apabila demikian keadaannya dapatkah agama diharapkan membantu manusia dalam mengatasi berbagai problem kehidupannya? Untuk menjawab pertanyaan ini jawaban sesungguhnya kembali kepada keinginan manusia itu sendiri, apakah ma- nusia akan membiarkan terjadinya pembusukan terhadap agama ataukah mereka akan mengembalikan agama pada fungsinya.

Dalam hal ini agama adalah "instrumens" bagi manusia untuk mewujudkan keinginannya, tetapi keinginan manusia selalu berubahberubah sehingga agama juga mengalami perubahan sesuai dengan keinginan manusia. Jadi, agama sesungguhnya tidak pernah mencapai perkembangannya yang final sehingga agama seolah-olah tidak memiliki tujuan yang pasti. Dalam hal ini manusia bersikap munafik terhadap agama (nya) sehingga terjadi pembusukan dan pertukaran peran secara silih berganti sepanjang waktu, yakni pada saat tertentu manusia membutuhkan agama, sedangkan pada saat lain agama memerlukan manusia.

Ratu Niyang adalah simbol kemahakuasaan Tuhan/Sang Hyang Widhi Wasa dalam manifestasiNYA sebagai pemberi kemakmuran bagi masyarakat. KehadiranNYA diyakini oleh masyarakat seperti tercermin dari hasil wawancara berikut ini.

\section{"Ida anak sweca pisan, nike mawinan akeh pisan semeton pedagang sane rawuh tangkil mariki" (wawancara dengan I Made Rona, Pamangku Pura Geria Any- ar). Informasi yang hampir sama juga di- peroleh dari Pamangku lainnya yaitu I Made Susila (55 tahun). \\ "Titiang nenten je purun, nanging akehan para pamedek meyakini Ratu Niyang swe- ca pisan, nike mawinan akeh pare pame- dek tangkit mariki"}

Berdasarkan hasil wawancara tersebut di atas dikaitkan dengan pandangan Hidayat dalam tulisannya berjudul Dialektika Agama dan Budaya, rupanya ada kesinambungan. Agama hendaknya mampu mentransendensikan diri, berada di atas pluralitas budaya dan bangsa, lalu memberikan visi, motivasi, dan pencerahan kemanusiaan dalam bingkai kebangsaan dan kebudayaan. Gerakan keagamaan pada akhirnya adalah gerakan kebudayaan karena manifestasi akhir dan perilaku seseorang tampil dalam ranah budaya. Dan jika sebuah agama tidak mampu mengartikulasikan diri dalam wadah budaya sebagai gerakan emansipatoris, maka agama akan ditinggalkan orang. Sebaliknya, gerakan kebudayaan yang tidak memiliki dimensi transen- 
den juga tidak akan mampu memperoleh dukungan abadi dan militan. Dalam pada itu, agama apapun pada akhirnya akan diuji oleh sejarah dengan ukuran-ukuran kemanusiaan secara empiris (Hidayat, 2003: 11). Dengan singkat dapat dikatakan bahwa agama sebaiknya melakukan reinterpretasi terhadap dogma-dogmanya sehingga selalu aktual dengan zamannya.

Dari paparan yang sangat mendalam tentang perkembangan agama-agama di dunia ketiga dalam buku berjudul Agama dan Modernisasi Politik, Suatu Kajian Analitis (1985) (dari judul asli Religion and Political Developmnet, An analitytic Study, 1970), Smith sampai pada kesimpulan bahwa modernisasi telah menyebabkan terjadi sekularisasi. Penelitian ini cenderung memvonis bahwa modernisasi dalam masyarakat secara otomatis akan melunturkan dan kemudian melenyapkan tradisi. Dalam kenyataannya modernisasi seringkali menjadi pelengkap dari tradisi dan sama sekali tidak menghapusnya. Pandangan Smith tersebut di atas kiranya perlu diuji di lapangan terutama menyangkut asumsi, modernisasi telah menyebabkan terjadinya sekulerisasi dan pudarnya tradisi. Apakah tradisi akan hilang atau akan selalu mengalami reinterpretasi sehingga pada akhirnya akan memunculkan tradisi baru lagi, menjadi pertanyaan menarik untuk dicermati.

Menurut Giddens (2003), tradisi adalah sebuah orientasi ke masa lalu bahwa masa lalu memiliki pengaruh besar, atau, secara lebih akurat, tradisi dibuat memiliki pengaruh yang besar pada masa sekarang. Namun jelas, dalam arti tertentu, tradisi adalah tentang masa depan, karena praktek-praktek yang telah mapan digunakan sebagai cara mengorganisasi waktu masa depan. Masa depan dibentuk tanpa perlu menganggapnya sebagai wilayah yang terpisah dengan masa lalu. Pengulangan, dalam sebuah hal yang perlu diteliti, merentang untuk membalikkan masa depan ke masa lalu, di samping mengambil masa lalu untuk merekonstruksi masa depan.

Tradisi selalu berubah-ubah, tetapi ada sesuatu tentang gagasan tradisi yang memiliki daya tahan jika bersifat tradisional, sebuah kepercayaan atau praktik yang memiliki integritas dan keberlanjutan, yang menentang desakan perubahan. Maka, integritas dan otentisitas sebuah tradisi memiliki arti lebih penting di dalam mendefinisikan sebuah tradisi dibandingkan la- manya sebuah tradisi dapat bertahan.

Lebih lanjut Giddens mengatakan, tradisi terkait dengan memori kolektif; tradisi melibatkan ritual, memiliki penjaga. Memori, seperti halnya tradisi adalah mengorganisasi masa lalu dalam kaitannya dengan masa sekarang. Masa lalu bukan sesuatu yang harus dipertahankan tetapi terus direkonstruksi berdasarkan masa sekarang. Rekonstruksi semacam itu sebagian bersifat individual, meskipun secara fundamental bersifat sosial atau kolektif. Tradisi adalah media pengatur memori kolektif.

Tradisi biasanya melibatkan ritual. Aspek ritual dari tradisi mungkin dianggap sekadar dari karakternya yang otomatis tanpa dipikirkan. Tetapi harus diingat bahwa tradisi pasti bersifat aktif dan interpretatif. Dapat dikatakan bahwa ritual terintegrasi ke dalam kerangka sosial yang akhirnya menyatukan tradisi; ritual adalah sebuah cara praktis memastikan keterpeliharaan tradisi. Ritual menghubungkan keberlanjutan rekonstruksi masa lalu dengan aktivitas praktis. Para penjaga tradisi seperti orang tua, dukun, ahli magi atau pejabat agama, memiliki peran penting dalam tradisi karena mereka dipercaya sebagai agen, atau mediator dasar dari kekuatan kausal tradisi.

Dari paparan tersebut kiranya dapat disepakati bahwa tradisi tidaklah statis tetapi bersifat aktif serta selalu mengalami reinterpretasi sehingga dapat berubah dari waktu ke waktu. Kebenaran dalam sebuah tradisi bisa berarti sebuah kebenaran yang bersifat cair sesuai dengan konteks zaman. Dapat dikatakan bahwa pemaknaan sosial terhadap objek berasal dari makna yang diberikan padanya melalui interaksi. Interaksi atau dunia sosial didefinisikan sebagai suatu tatanan yang dirembugkan secara temporer; jelasnya ia harus dibangun kembali secara terus menerus untuk menafsirkan dunia (Coulon, 2008: 11)

\section{PENUTUP}

Pemujaan Ratu Niyang di Kota Denpasar, adalah keberlanjutan dari bentuk kepercayaan para Hindu yang menggunakan simbol perempuan sebagai bentuk kemahakuasaan Tuhan/ Sanghyang Widhi Wasa sebagai Dewi Kesuburan, Dewi Kemakmuran. Penggunaan simbol perempuan dalam hal ini adalah sebagai upaya mempermudah pemahaman bagi masyarakat 
awam terhadap kemahakuasaan Tuhan/Sanghyang Widhi Wasa yang sangat abstrak. Pemujaan Ratu Niyang di Kota Denpasar memiliki fungsi Religius Ekonomisdan Fungsi Sosial.

Fungsi Religius Ekonomis dibuktikan dengan banyaknya masyarakat yang datang menghaturkan sembah di Pura Geria Anyar Tanah Kilap Suwung dan meyakini bahwa Ida Sanghyang Widhi dengan segala prabawaNya yang bersthana di pura ini sangat pemurah dan mampu memberikan kesejahteraan bagi masyarakat yang meyakininya.

Fungsi Sosial dibuktikan dengan banyak masyarakat yang datang ke Pura Geria Anyar Tanah Kilap Suwung yang merupakan sebuah sistem keyakinan dan praktek dari masyakarat yang disatukan dengan hal-hal yang sakral yang ter- kait dengan komunitas moral dan tunggal, disamping itu masyarakat yang datang ke Pura Geria Anyar Tanah Kilap Suwung juga membangun solidaritas sosial sesama masyarakat yang datang beribadah. Makna Pemujaan Ratu Niyang di Kota Denpasar adalah ; (1) Makna Penguatan Keimanan kepada Tuhan Yang Maha Esa adalah kehadiran Pura Gria Anyar Tanah Kilap sebagai tempat pemujaan Ratu Niang telah memberikan vibrasi positif terhadap proses pengembangan keimanan kepada Tuhan Yang Maha Kuasa Ida Sang Hyang Widhi Wasa bagi masyarakat. (2) Makna Kesejahteraan, Ratu Niang adalah simbol kemahakuasaan Tuhan atau Ida Sang Hyang Widhi Wasa dalam Manifestasinya sebagai pemberi kemakmuran bagi masyarakat.

\section{DAFTAR PUSTAKA}

Agung, Anak Agung Gde Putra. 2001. Perubahan Sosial dan Pertentangan Kasta di Bali Utara. Yogyakarta : Yayasan Untuk Indonesia.

Aiken, Henry D. 2009. Abad Ideologi. Jogjakarta: AR-RUZZ

Ali, Sayuthi. 2002. Metodologi Penelitian Agama, Pendekatan Teori dan Praktek. Jakarta : PT. Raja Grafindo Persada.

Ardana, I Gusti Gede. 1986. "Local Genius dalam Kehidupan Beragama”, dalam Kepribadian Budaya Bangsa. Editor : Ayatrohaedi. Jakarta : Pustaka Jaya.

Arivia, Gadis. 2009. Yang Sakral dan Yang Sekuler. Jakarta: Yayasan Jurnal Perempuan.

Atmaja,Nengah Bawa. 2002. Metode Penelitian Kualitatif. Makalah, disampaikan pada Penataran Dosen Muda IKIP Negeri Singaraja Pola 90 Jam. Singaraja : IKIP Negeri.

Bosch, F.D.K. 1983. Masalah Penyebaran Kebudayaan Hindu di Kepulauan Indonesia. Jakarta : Bhratara Karya Aksara.

Bungin, Burhan. 2003. Analisis Penelitian Kualitatif, Pemahaman Filosofis dan Metodologis ke arah Penguasan Model Aplikasi. Jakarta: PT.Raja Grafindo Perkasa.

Endraswara, Suwardi. 2003. Metodologi Pnelitian Kebudayaan. Yogyakarta: Gadjah Mada University Press.

2006. Metode, Teori, Teknik Penelitian Kebudayaan. Ideologi, Epistemologi, dan Aplikasi. Sleman : Pustaka Widyatama.

Geriya, I Wayan. 2000. Transformasi Kebudayaan Bali Memasuki Abad XXI. Denpasar : Percetakan Bali.

Gulo, w. 2002. Metodologi Penelitian. Jakarta. Grasindo.

Hidayat, Komaruddin dan Nafis, Muhamad Wahyudi.2003. Agama Masa Depan, Perspektif Filsafat Perenial. Jakarta : PT. Gramedia Pustaka Utama.

Yudari. 2015. Tesis “Dimensi Sosial Budaya Perempuan Hindu Bali Dalam Kasus Kekerasan Rumah Tangga di Wilayah Poltabes Denpasar".

Kahmad, H. Dadang. 2000. Metode Penelitian Agama, Perspektif Ilmu Perbandingan Agama. Bandung : Pustaka Setia. 
Koentjaraningrat, 1987. Sejarah Teori Antropologi. Jakarta : UI-Press

2002. Kebudayaan Mentalitas dan Pembangunan. Jakarta :PT Gramedia Pustaka Utama

Lauer, Robert H.2003. Perspektif Tentang Perubahan Sosial. Jakarta : Rineka Cipta.

Magetsari, Noerhadi.1986. "Local Genius dalam Kehidupan Beragama”, Ayatrohaedi (ed.) dalam Kepribadian Budaya Bangsa. Jakarta : Pustaka Jaya

Mantra, I.B. 1996. Landasan Kebudayaan Bali. Denpasar: Yayasan Dharma Sastra.

MasPutra. 2006. UpacaraManusaYadnya. Denpasar: KanwilDepartemen Agama Provinsi Bali.

Nala. Ngurah dan Wiratmaja. 1989. Murdha Agama Hindu. Denpasar: Upada Sastra.

Nashir, Haedar. 1999. Agama \&KrisisKemanusiaan Modern. Yogyakarta: Pustaka Pelajar.

Nordholt, Henk Schulte. 2006. The Spell of Power. Sejarah Politik Bali 1650 - 1940. Jakarta : KITLV

O’Dea, Thomas F. 1985. Sosiologi Agama. Jakarta: CV. Rajawali.

Pemda Tingkat I Bali. 1985/1986. Sejarah Perkembangan Agama Hindu di Bali. Denpasar : Proyek Penyuluhan Agama dan Penerbitan Buku Agama.

Radhakrishnan. R. 2003. Agama-Agama Timur dan PemikiranBarat. Denpasar: Program Magister Ilmu Agama dan KebudayaanUniversitasHindu Indonesia bekerja sama denganpenerbitWidyaDharma.

Subagya, Rachmat. 1981. Agama Asli Indonesia. Jakarta: Sinar Harapan dan Yayasan Cipta Loka Caraka.

Sudikan, Setya Yuwana. 2001. Metode Penelitian Kebudayaan. Surabaya: Citra Wacana.

Sunardi,St. 2003. “Kajian Budaya: Pada Mulanya adalah Perlawanan..., dalam Retorik, Jurnal IIlmu Humaniora Baru, Volume 2 No.4 Oktober 2003.

Sutaba, I Made. 1980. Prasejarah Bali. Denpasar : BU. Yayasan Purbakala Bali. 